\title{
Comparing social representation of water quality in coastal lagoons with normative use of ecological indicators
} \author{
Audouit Christelle ${ }^{1,{ }^{*}}$, Pasqualini Vanina ${ }^{2,3}$, De Wit Rutger ${ }^{4}$, Flanquart Herve ${ }^{5}$, Deboudt Philippe ${ }^{1}$,
Rufin-Soler Caroline ${ }^{5}$
}

${ }^{1}$ Univ Lille Sci \& Technol, EA 4477, TVES, F-59000 Lille, France.

2 Univ Corsica, CNRS, UMR 6134, SPE, BP 52, F-20250 Corte, France.

${ }^{3}$ Univ Corsica, CNRS Stella Mare, UMS 3514, BP 52, F-20250 Corte, France.

${ }^{4}$ Univ Montpellier, CNRS, IFREMER, UMR MARBEC,IRD, PI Eugene Bataillon,Case 093, F-34095

Montpellier 5, France.

${ }^{5}$ Univ Littoral Cote dOpale, EA 4477, TVES, F-59140 Dunkerque, France.

* Corresponding author : Christelle Audouit, email address : christelle.audouit@univ-lille1.fr

\begin{abstract}
:
Coastal lagoons are important for coastal and marine biodiversity. Nevertheless, they are very sensitive and vulnerable to human impacts, which often result in a decrease of their biodiversity and degradation of their water quality. Considering recent efforts for ecological restoration of coastal lagoons, it appears appropriate to compare the social representations of users of the coastal lagoons and of inhabitants, with ecological diagnoses of biodiversity and water quality. The main question is whether there is congruence between water quality defined by environmental criteria on one hand and the social representations of these issues by lagoon users and local populations on the other hand? How can we explain the social representations of lagoons concerning landscape, water quality and biodiversity? This study was focused on two Mediterranean lagoon areas, i.e., the Palavas lagoon complex (Gulf of Lions) and Biguglia lagoon (Corsica). We have documented these changes of ecosystem states using the criteria of regional monitoring programs that anticipated the implementation of the Water Framework Directive (WFD). Accordingly, both systems have shown bad water quality in the past with recent improvements. For studying the social representations, we conducted 267 surveys with lagoon inhabitants that live close to the lagoons and users of these spaces. In general, most of the residents living close to the lagoons considered that water quality is moderate to good, that biodiversity is good to high and that the current situation is better than in the past. However, some discrepancies between social representations and ecological diagnoses were observed.
\end{abstract}




\section{1-Introduction}

Coastal lagoons occupy $13 \%$ of the world's coastline [1]. Lagoons have been of great interest to human societies because these ecosystems support high biological productivity and are the support of economic and sociocultural activities. However, many of these ecosystems have suffered ecological degradation particularly due to human impacts including nutrient over-enrichment, contamination and habitat destruction. These human impacts concern the lagoons worldwide [2,3]. Environmental awareness in certain countries has resulted in actions for combating the pressures and initiating ecological restoration of coastal lagoons in order i) to reduce natural risks (e.g., combating flood risks), ii) to stop the loss of biodiversity [4], iii) to improve the water quality [5], and iv) to eliminate invasive species [3]. Thus, many actions have been carried out such as Barcelona Convention for the protection of the marine environment and the coastal region of the Mediterranean in 1995 and the European Union Water Framework Directive 2000/60/CE (WFD) in 2000. In addition, in 2005, the Mediterranean Ecosystem Approach Strategy was proposed aimed to decontaminate the Mediterranean Sea and to achieve a Healthy Environment status by 2020.

The main purpose of the WFD is the protection and where necessary restoration of water quality of surface waters, including coastal lagoons. The final objective is to achieve at least good ecological status for all water bodies with clear milestones defined by the end of three different management cycles finishing in 2015, 2021 and 2027, respectively [6]. According the WFD, good status is defined as 'small' deviation from the reference conditions of a surface water body type; while the Mediterranean coastal lagoons are considered to belong to the transitional waters type in the Mediterranean ecoregion. The WFD also provides the guidelines and framework for the assessments of the ecological quality status of aquatic ecosystems [7]. But, because of the subsidiarity principle, the member states developed their own monitoring programs and assessment systems, which have been intercallibrated within the Ecoregions [8, 9].

The Western Mediterranean and the French Mediterranean coastline are also considered regional biodiversity hotspots and comprise a high concentration of vulnerable ecosystems where the aims are to reduce human pressures and to increase conservation [10]. Recent studies underscored the need for a holistic approach to assess the vulnerability of ecosystems to natural processes [11]. Hence, the study of the interactions between the natural processes and human dynamics and their resulting pressures on coastal lagoons implies that all dimensions of the coastal lagoon socio-ecosystem should be considered. The main objective of this study is to combine methods from different disciplines, each with their 
individual concepts and know-how. These included aquatic ecology, geography and sociology. The latter two disciplines adopted a real interdisciplinary approach, which results were compared to the ecological data to articulate knowledge on a similar object, i.e. the selected lagoons. Research about the social representation and perception of the common public is a prerequisite in this respect. One of the social objectives of this research is to study initially, how the local people perceive this improvement of water quality, and secondly, which are their representations of these lagoons. Are there differences between the water quality assessments according the normative approaches implemented by the WFD and the social representations? If there are any differences, how can these be characterized? To answer these questions, the ecologists made an ecological assessment of the lagoons using monitoring data collected over approximately ten years and applying the French system for assessing the ecological quality status for transitional waters in the Mediterranean Ecoregion. The geographers and the sociologist were interested in the social representations of the residents and users of lagoons.

In this paper, the case studies include two French Mediterranean lagoon complexes (e.g. the Palavas lagoon complex and Biguglia lagoon). Three reasons explain the justifications of these case studies. First, these lagoons situated in the proximity of major urban centers [12] and have, therefore, been subjected to many of the urban pressures cited above. Second, the French assessment system for the WFD described the water quality initially as bad to poor, but it has improved gradually after the recent ecological restoration efforts [13, 4]. Third, the two systems differ with respect to spatial planning [12], ownership and management. The Palavas lagoon complex (Fig. 1) comprises seven lagoons with a surface of 3,880 ha. Together with their fringing wetlands, the surface exceeds 6,000 ha. Since the 1960s, this territory has been very attractive and has undergone high demographic growth; presently, the urban agglomeration Montpellier Méditerranée Métropole has more than 400,000 inhabitants. This resulted in a high level of urbanization near the lagoons with various types of pollution and degradation of these ecosystems. These lagoons have suffered from nutrient over-enrichment for four decades until 2005 [13,14]. The surface of 11km long, Biguglia lagoon (Fig. 1) is 1,460 hectares. Since 1999, the territory of the Biguglia lagoon has been subjected to a strong demographic pressure [12]. Bastia, the town just located north of the lagoon, comprises more than 40,000 inhabitants and the municipalities located nearest to the Biguglia lagoon have each between 5,000 and 8,000 inhabitants. Biguglia lagoon has been profoundly altered for 40 years by nutrient inputs and poor hydrological management [15]. 


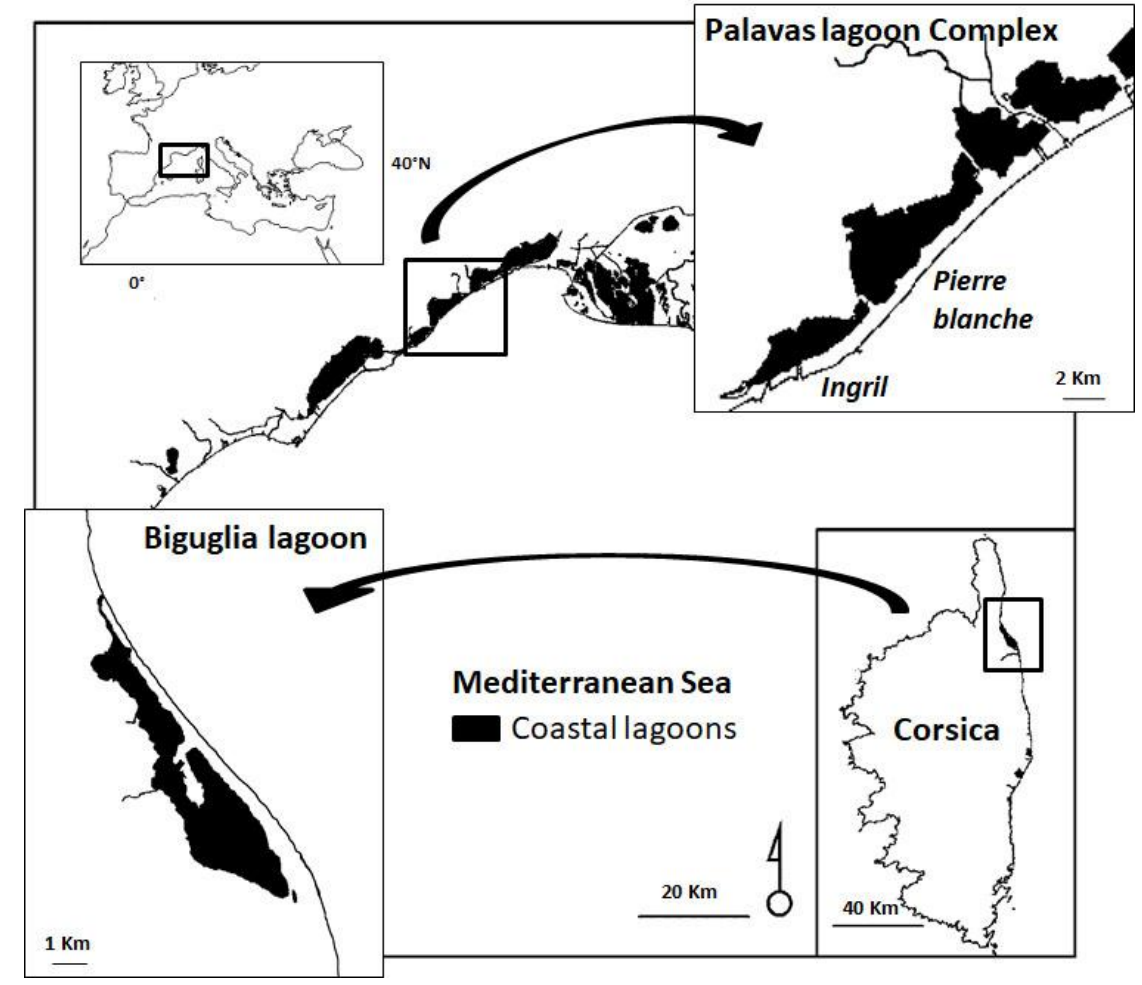

Fig. 1: Map of Palavas complex and Biguglia lagoons

\section{2- Material and methods}

\subsection{Material and methods to describe the water quality with the criteria of WFD}

The assessment of the ecological quality status according WFD guidelines is based on measuring Ecological Quality Ratios (EQR) using biological quality indicators (BQI), which are translated into quality classes. The overall score for the ecosystem is based on the principle "one out all out" [7]. The database developed by the Lagoon Monitoring Network (Réseau de Suivi Lagunaire) has been used to evaluate the eutrophication status of lagoons [13]. This network has pioneered the use of bioindicators in the Mediterranean lagoons to gauge the ecological status and provided the basis for the French assessment of ecological quality status for the WFD in Mediterranean transitional waters (see Annexe Table). Hence, submerged macrophytes and phytoplankton have been used as biological quality indicators (BQI) of lagoon ecological status, because they display community-level responses to nutrients in the water [16,17]. Physicochemical parameters such as inorganic nutrient concentrations were used to describe the physicochemical status of water. Concerning the Palavas lagoon complex, the data used comprised 2004 and 2011, before and after the installation of a new wastewater treatment plant, respectively. Concerning the Biguglia lagoon, the data were not collected every year and we have considered two periods, from 2003 to 2009 and from 2009 to 2014. 


\subsection{Method based essentially on qualitative data to describe the social representations of users and residents of Palavas and Biguglia lagoons}

The theory of the social and mental representations was developed during the 1960-1970s by Moscovici $[18,19]$. French geographers have been interested in social representations since the 1970s [20,21]. Social representation has been described as a collective phenomenon pertaining to a community, which is constructed collectively by the individuals of that community in their daily talk and action. Hence, it can be defined as the ensemble of thoughts and feelings being expressed in verbal and overt behavior of stakeholders, which constitutes an object for a social group [22]. Social representations are the interpretative filters of reality. The social representations are an abstraction and a synthesis carried out of the true life experiences, repeated perceptions and the movements realized. It is a discontinuous, indistinct and unfinished, not an objectively true representation, which depends on partial information. It has been built with each one of us advents, based on the perceptions and knowledge accumulated since childhood [23].

In order to compare studies, the methodology was the same for the two lagoon systems. One hundred forty two lagoons users (91 for Palavas lagoon complex and 51 for Biguglia lagoon) have been interviewed by semi-structured talks on the emblematic sites ${ }^{1}$ of the lagoons. The guided discussion structure contains seven parts including one on the perception and the representation of the landscapes of the lagoon and one on how the management evolved over time and is perceived. During this paper, this survey concerning to users will be called "survey A". One hundred twenty five inhabitants (53 for Palavas lagoon complex and 72 for the Biguglia lagoon) were interviewed face to face in the streets using questionnaires, in order to know the percentages of those who do not visit the lagoons. To achieve a double coherence in the results obtained for both lagoons, a pair of municipalities has been chosen. Between the lagoons, the selected municipalities were comparable with respect to population characteristics $^{2}$. Each pair comprised one selected municipality that included a part of the lagoon surface in its municipal territory, i.e., Villeneuve-lès-Maguelone and Furiani for the Palavas complex and Biguglia lagoons, respectively. The second municipality in each pair was a suburban municipality located at a distance of 5 to $10 \mathrm{~km}$ ) from the lagoon, i.e. Fabrègues and Vescovato ${ }^{3}$ for the Palavas complex and Biguglia lagoons, respectively. Based on their knowledge of the local context, the managers of the lagoons approved the

\footnotetext{
${ }^{1}$ Defined with the SIEL (Syndicat Mixte des Etangs Littoraux) and with the Réserve Naturelle de l'étang de Biguglia.

${ }_{2}$ According to socio-economic categories, gender, age and in size of population.

${ }^{3}$ The population of Vescovato did not want to participate in the questionnaire; we investigated to Bastia according to the advice of the manager [38].
} 
choice of methodology. This second survey concerning to inhabitants will be called "survey B".

Six photographs have been chosen as supporting material for the semi-structured interviews and questionnaires (surveys $\mathrm{A}$ and $\mathrm{B}$ ). People choose the photograph that, according their opinion, was most representative for the landscape. The photos were specific for the fieldworks.

This study is based mainly on comparing and combining the qualitative data and the quantitative data. Only three closed questions of survey B were used and interpreted quantitatively, which were completed with and strengthened by qualitative data when it was possible. Quantitative treatment of the data gives the trends of the perceptions and feelings, verbatim provides the wording that illustrate these trends and clarifies the perceptions. Topics concerning water quality and biodiversity concerned less than ten questions because that was not the main object of the REPERBIPa project [24].

The data from the questionnaires (B survey) were treated by cross-tabulation analysis [25]. The relatively small size of the sample does not allow more sophisticated processing (as e.g., a factorial analysis). To obtain the confirmation that certain sociodemographic variables (e.g., age) have an effect on the representation of the inhabitants, chi-square test or Fisher's exact test were made every time. The semi-structured interviews (A survey) were treated in two ways: first, the interviews were analyzed in depth to understand the representation of the coastal lagoons users and extract significant verbatim [25], then the questions adapted for statistical treatment were analyzed by cross-tabulation, like for the B survey.

\section{3- Results}

\subsection{Improvement of water quality (Ecological diagnoses)}

The eutrophication indicators from the monitoring program (Lagoon monitoring network) and the assessment of ecological quality showed that the water quality of Palavas lagoon complex have improved since 2005 [13], after the Montpellier Waste Water Treatment Plant was upgraded and its effluents have been discharged $11 \mathrm{Km}$ offshore. Nevertheless, the improvement has been less pronounced for the heavily impacted lagoons (hysteresis). In 2004, eight of ten stations were in a bad ecological state and only one was in a good ecological state. Six years after, only two of eleven were in a bad ecological state but only two were in a good ecology state [13]. In 2011, two of the three indicators were assessed as 
good for Ingril and only the macrophyte indicator was moderate. In contrast, while some improvement was observed for Pierre Blanche between 2004 and 2011, the indicators still ranged from poor to moderate in this lagoon (Fig.1 and Table 1).

Concerning Biguglia lagoon, from 2003 to 2009, the water quality was described as poor or bad according the French WFD assessment, while it has improved gradually after the recent restoration efforts (from 2009 to 2014; Table 1). Nevertheless, while only the physicochemical conditions of the water column were good for the latter period, phytoplankton and macrophytes improved marginally to poor and moderate, respectively.

Recent ecological restoration efforts correspond to improved treatment of urban effluents and increased hydrological conditions of the lagoon.

Table 1: The water quality from the indicators of eutrophication for Biguglia lagoon (20032014) and two selected lagoons in Palavas lagoon complex (2004-2010) - Source [26,27,28]

\begin{tabular}{|l|l|l|l|}
\hline Period & Physico-chemical of water & Phytoplankton & Macrophytes \\
\hline \multicolumn{4}{|c|}{ Biguglia lagoon } \\
\hline $2009 / 2014$ & Good & Poor & Moderate \\
\hline $2003 / 2009$ & Poor & Bad & Poor \\
\hline \multicolumn{5}{|c|}{ Pierre Blanche lagoon in Palavas lagoon complex } \\
\hline 2011 & Moderate & Poor & Poor \\
\hline 2004 & Bad & Bad & Poor \\
\hline \multicolumn{5}{|c|}{ Ingrid lagoon in Palavas lagoon complex } \\
\hline 2011 & Good & Good & Moderate \\
\hline 2004 & Moderate & Poor & Moderate \\
\hline
\end{tabular}

3.2 Positive social representations: from water quality to biodiversity of the lagoons, fringing wetlands and beaches

Generally, inhabitants of the two lagoon systems show a social representation of water quality that is more optimistic than the ecological assessment based on bioindicators (Table 1 and Fig.2). In 2014, for Palavas lagoon complex, more than half interviewees considered 
that the water quality was good or moderate and a quarter answered that the water quality was bad or poor (survey B). For Biguglia lagoon, the majority of the interviewees considered that the water quality was good or moderate (survey B). Yet, for Biguglia lagoon, people who considered that water quality was bad were proportionally more numerous than that of the inhabitants living close to the Palavas lagoon complex adopting this opinion, and the results show an effect of age structure (Fisher test, $\mathrm{N}=45, \mathrm{p}=0.05$ ). The half of this one third was the youngest age categories, and more people were old, less they were numerous to share this opinion.

The interviewers did not directly question the users about their perception of the water quality, but they inquired the inhabitants living close to the lagoons (B survey). When inhabitants never go to lagoons, the interviewers stopped directly the questionnaire; in that case, they did not ask the question about the water quality. For the Palavas lagoon complex, one fifth of interviewees could not answer because they never visit the lagoon complex, and for Biguglia lagoon, this was the case for one third of the interviewees. The results do not show a effect of site (Fisher test, $\mathrm{N}=98, \mathrm{p}=0.83$ ).

To compare results of each study (ecological diagnoses and social representations), the five quality states for the water quality proposed in the questionnaire are the same as those used by the WFD, i.e., high; good; moderate; bad; and poor.

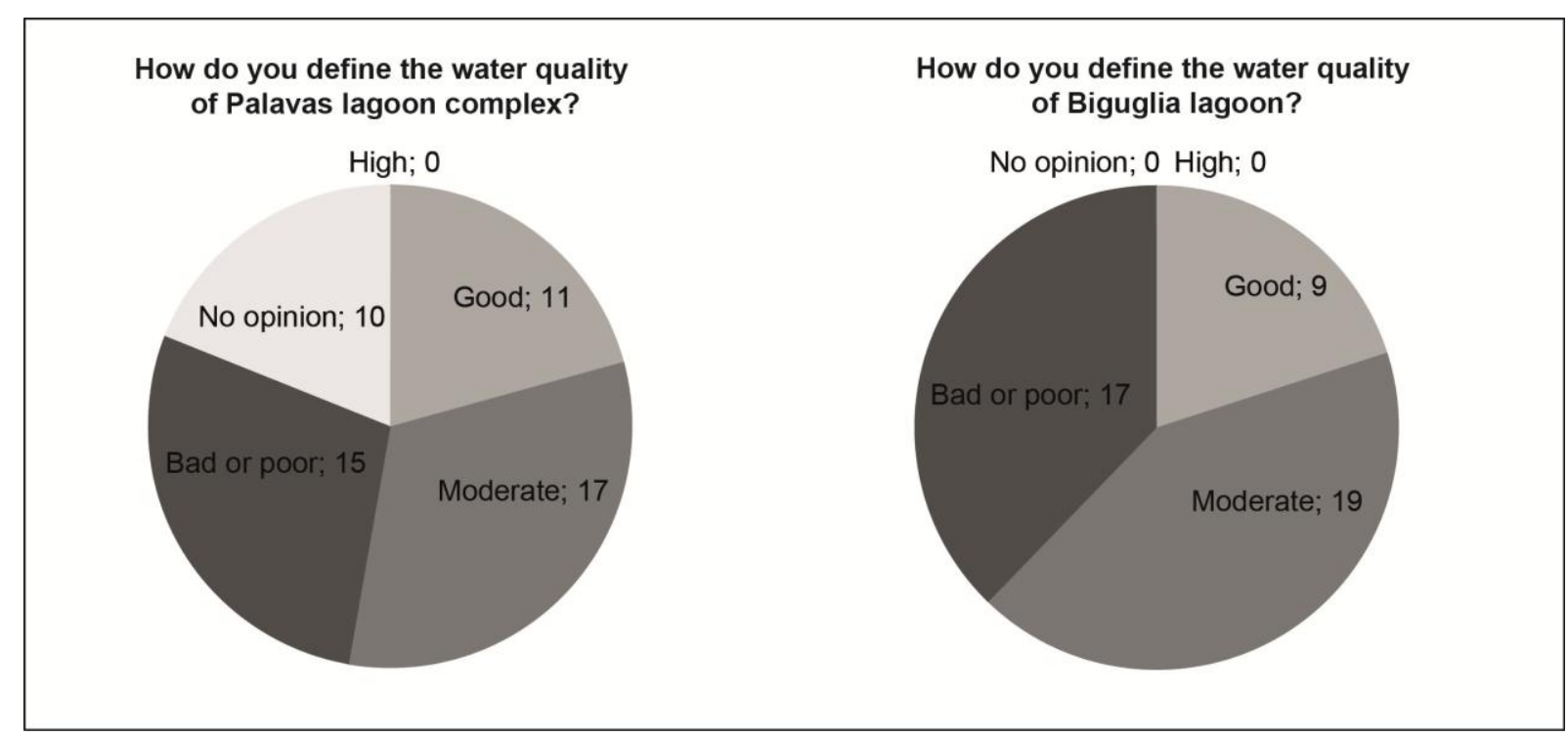

Fig. 2: Social representation of water quality of Palavas complex and Biguglia lagoons by inhabitants (2014) (Survey B) 
The results of social representations about biodiversity help to understand those of the water quality, because the biodiversity is a consequence from the water quality. The inhabitants considered the biodiversity, easier to see for them, higher than the water quality (Fig.3). Nobody thinks that the water quality was high, whereas one third of interviewees of both lagoons considered the biodiversity as high, and more than another third of the interviewees considered the biodiversity of lagoons as good (B survey) (Fig.2 and Fig.3). The results do not show an effect of site on the social representation of biodiversity (Fisher test, $N=88$, $p=0.13)$. For this closed-ended question of the questionnaire, the interviewees could choose one answer among five, the same answers as for the water quality (ecological diagnoses and social representations), except for "moderate" which was not proposed for the biodiversity, and the response modalities "poor" and "bad" divided in two modalities.

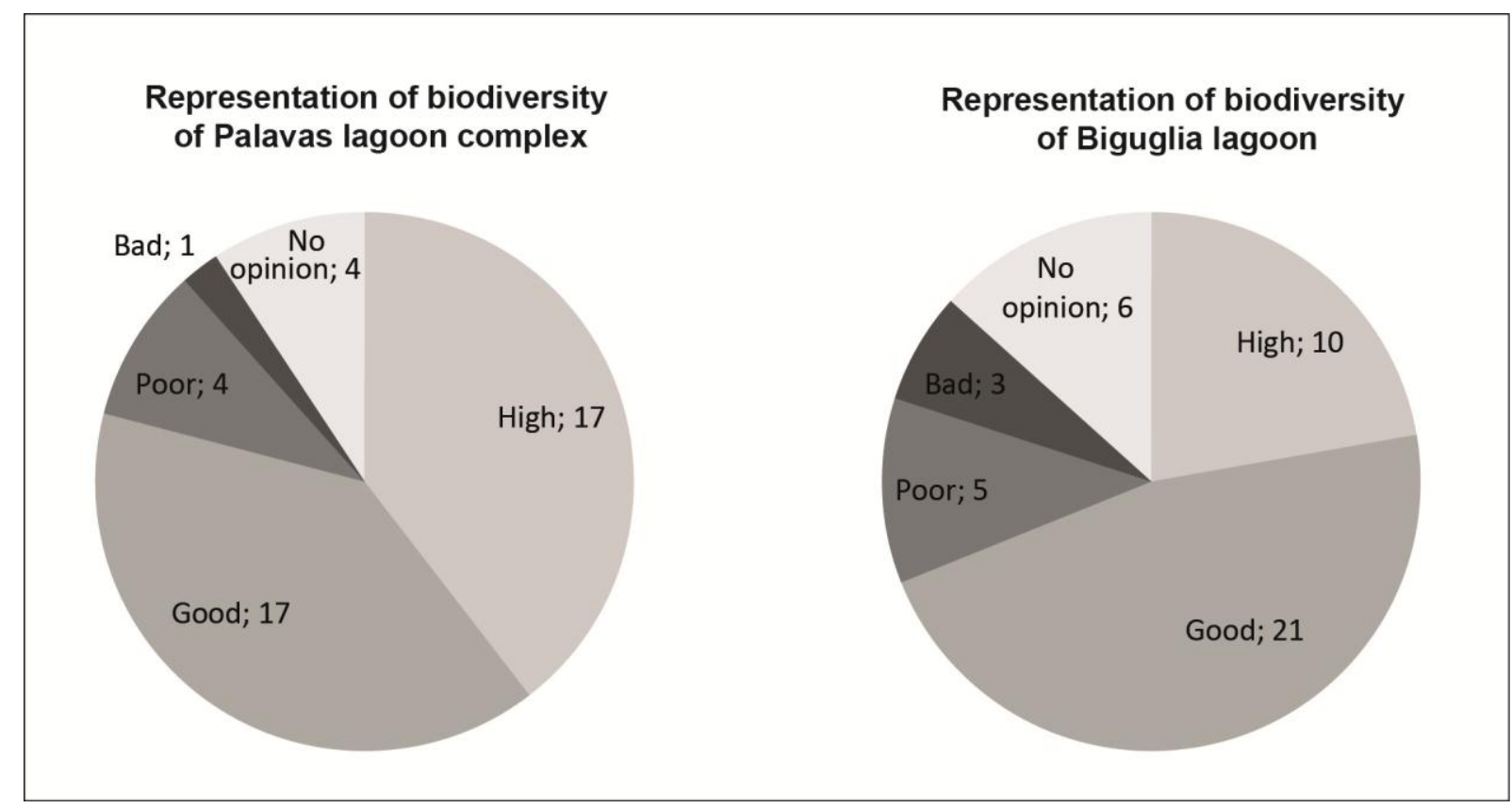

Fig. 3: Social representation of the biodiversity of Palavas complex and Biguglia lagoons by the inhabitants - (2014) (Survey B)

The biodiversity is characterized by the visible presence of animals or plants for people. For both lagoons, the inhabitants considered the principal representative animal species were the birds (B survey): more than 40 responses on 55 to 58 responses to the open-ended question, "In your opinion, what animal species are the most iconic animals of the areas?" (Fig.4). Fishes, which are hardly visible for most people, and other animal species were rarely mentioned. However, the interviewed people showed very little knowledge about the animal species living in the lagoons. Often they invoked generalities only as "birds" or "fishes" and emblematic "Greater Flamingo". In the Palavas lagoon complex, Greater 
Flamingo was the most symbolic animal species for half of the respondents. In the Biguglia lagoon, "birds" and "Greater Flamingo" were the most representative animal species for one fifth of the interviewees (Fig.5).

People associated the efforts of maintenance, accessibility with management for the improvement of biodiversity and landscape. More than half interviewees who declared that they found the landscape have changed for the last ten years, claimed, "There are more fishes", "more vegetation", "more maintenance", "less pollution" when the interviewers asked the open-ended question: "Have you observed the landscape developments on those sites for ten years? If yes, what are they?". This question was the last question about the biodiversity in the questionnaire.

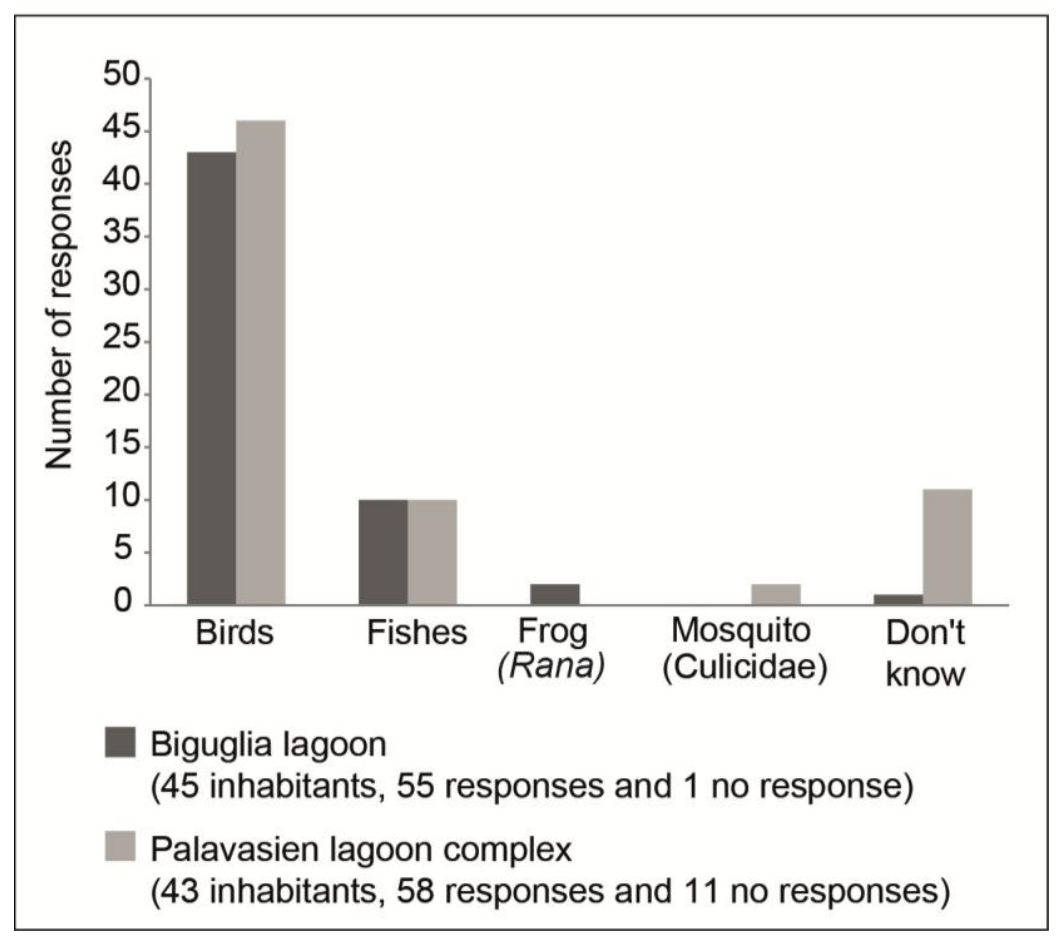

Fig. 4: The most representative animal species of Palavas complex and Biguglia lagoons for inhabitants - (2014) (open-ended question in survey B) 


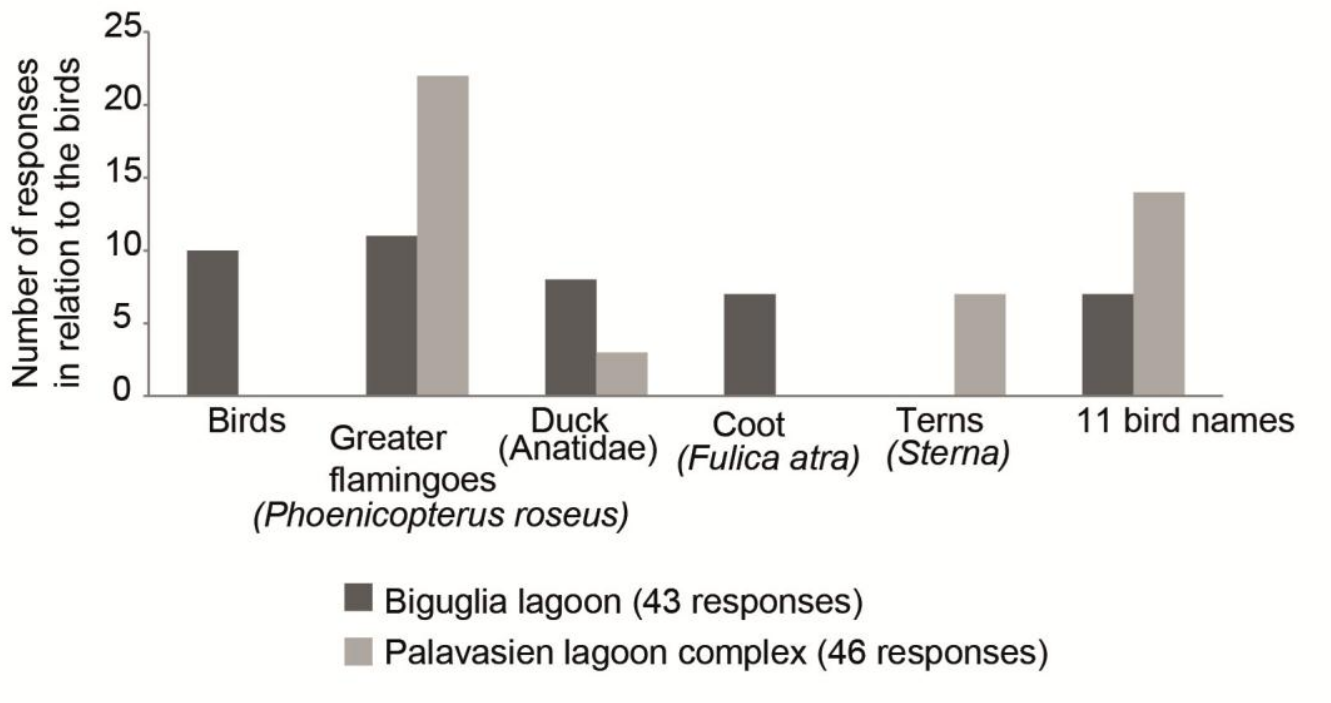

Fig. 5: The most representative animal species of Palavas complex and Biguglia lagoons for inhabitants but only in relation to birds - (2014) (the same open-ended question dealt in the Fig.4, survey $B$ )

\subsection{Effects of age structure on social representation of landscape and the opinion about the} utility to continue to preserve the Biguglia lagoon

For Biguglia lagoon, the age was an explanatory variable of the social representations of the Biguglia lagoon landscapes (Fisher test, $\mathrm{N}=93, \mathrm{p}=0.02$ ( $\mathrm{A}$ and $\mathrm{B}$ surveys). At the question, "According to you, what is the photograph which best represents the landscape of this lagoon?", half of the young people indicated the photo of the beach (photo 1 in Fig.6) as the most representative of the landscape of the lagoon. In fact, the youngest age categories used this territory for its seaside activities. These were concentrated on the beach, not on the lagoon: "The lagoon does not represent a special meaning for me, I go here to enjoy the beach", (Interview on the Marana beach, A survey, girl 17 years old in 2014). The Fornagina Parc has created in health path since 2006. The majority of people who came in this section of lagoon, were the runners. It is for that reason that those under the age of 44 chosen the photo 5 (Fig.6). The half of the oldest age category (above 60 years) indicated the photo 4 and the photo 3 that show the places of fishing when, more than 20 years ago there was no ban for the recreational fishing (Fig.6).

For the Palavas lagoon complex, the test results with the photos show that, the socioeconomic categories, i.e. the age or gender, were not significant explanatory variables of the social representations of the landscapes and the choice of species symbolic systems (Fisher test, $\mathrm{N}=137, \mathrm{p}>0.05$ ) (A and $\mathrm{B}$ surveys). 


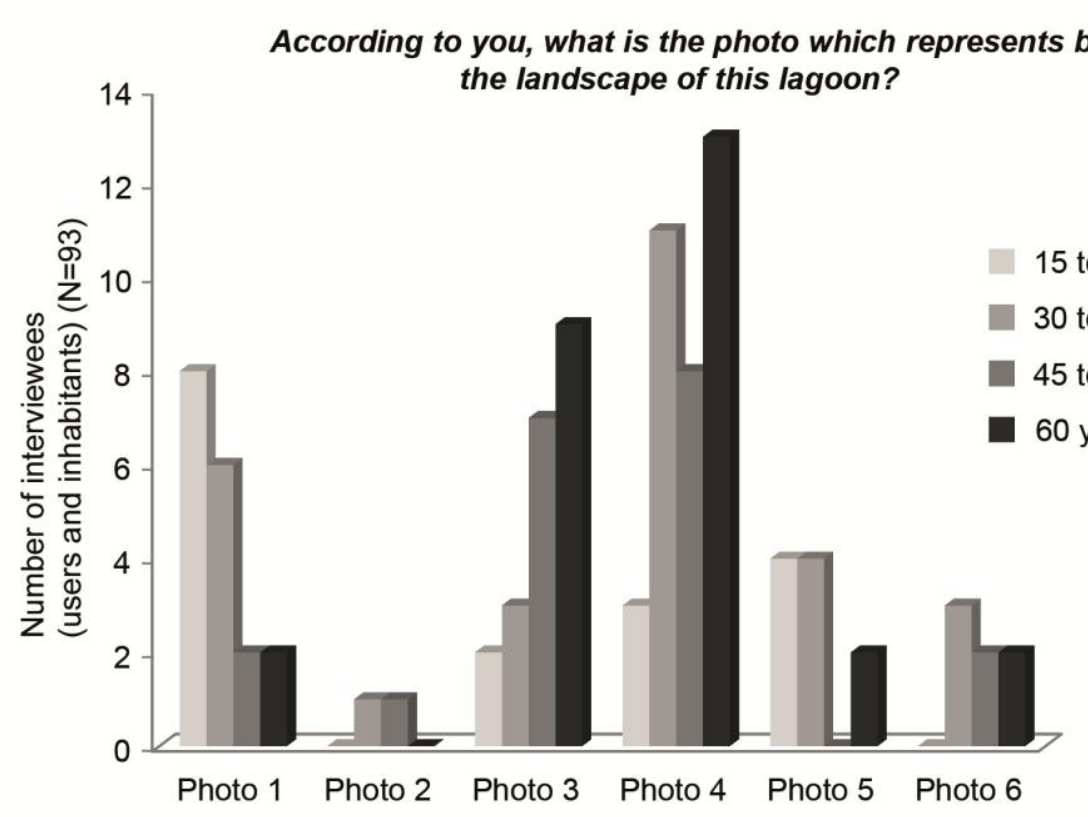

Photo 1

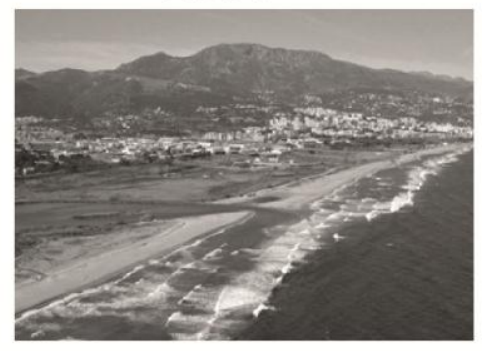

View of Banda Bianca beach (north of the lagoon) with the mountains and Bastia in the background.

Photo 4

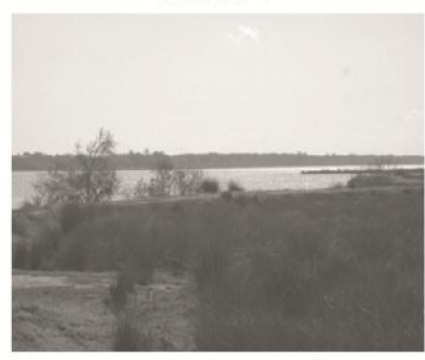

View over the lagoon from Fortin ecomuseum (created in 2008).
Photo 2

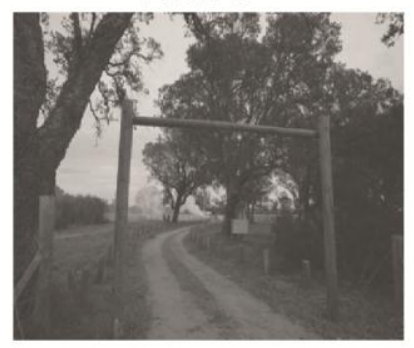

Entrance of the Parc Fornacina, a 20 ha recreational park created in 2006.

Photo 5

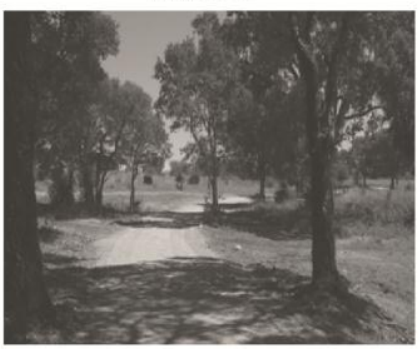

Part of Parc Fornacina most distant from the lagoon shore.
15 to 29 years old

30 to 44 years old

45 to 59 years old

60 years old and more

Fig. 6: Effects of the age structure on the social representation of landscape of Biguglia lagoon of users and inhabitants - (2014) (Surveys $A$ and B) 
The opinions on the utility to continue or not the preservation were differences one lagoon to another, because managing are differences. For the Palavas lagoon complex, less than half of the people considered that it is necessary to continue to protect lagoons, more than half of the inhabitants did not take position (B Survey) (Fig.7). Certain users did not agree to pay for access to the beach: "We may soon have to pay for access to the beach." (Man, Aresquiers beach, 2014, A survey). Others users found there was less access: "Before, users could walk everywhere, but now there are less footpaths and there aren't more birds than before. The site is so closed" (Man, 60 years old, Villeneuve-lès-Maguelone beach, 2014, A survey). "I regret the time when the site wasn't regulated because I prefer to walk off the paths. I prefer to decide for myself the way I take", (Woman, Maison de la Nature, 2014, A survey). Furthermore, numerous users considered that the users of the sites did not respect the regulation (A survey). The institutions or public authority applicated the regulation too little. The problem was the conflicts between users: "more policemen to control where necessary. Perhaps regulating certain activities at specified times... people have the disrespectful behaviors... People do not respect the sites and regulations" (Woman, Bois des Aresquiers, 2014, (A survey).

For Biguglia lagoon, more than three-quarters of the inhabitants interviewed considered that it was important to continue to protect this lagoon while one fifth did not pronounce an opinion (survey B). "The important issue is to preserve" (Woman, Ecomuseum at Biguglia lagoon, 2014, survey A). The results show an effect of age structure on opinion about the utility to continue to preserve the lagoon (Fisher test, $N=45, p<0.0001$ ). Nine for eleven young people did not know if the lagoon had to continue to be preserved (B survey) (Fig.8). In the guided discussion, the open-ended questions on regulation to preserve this site completed the results of the closed-ended question in the questionnaire: the aim was to know the arguments of interviewees. 


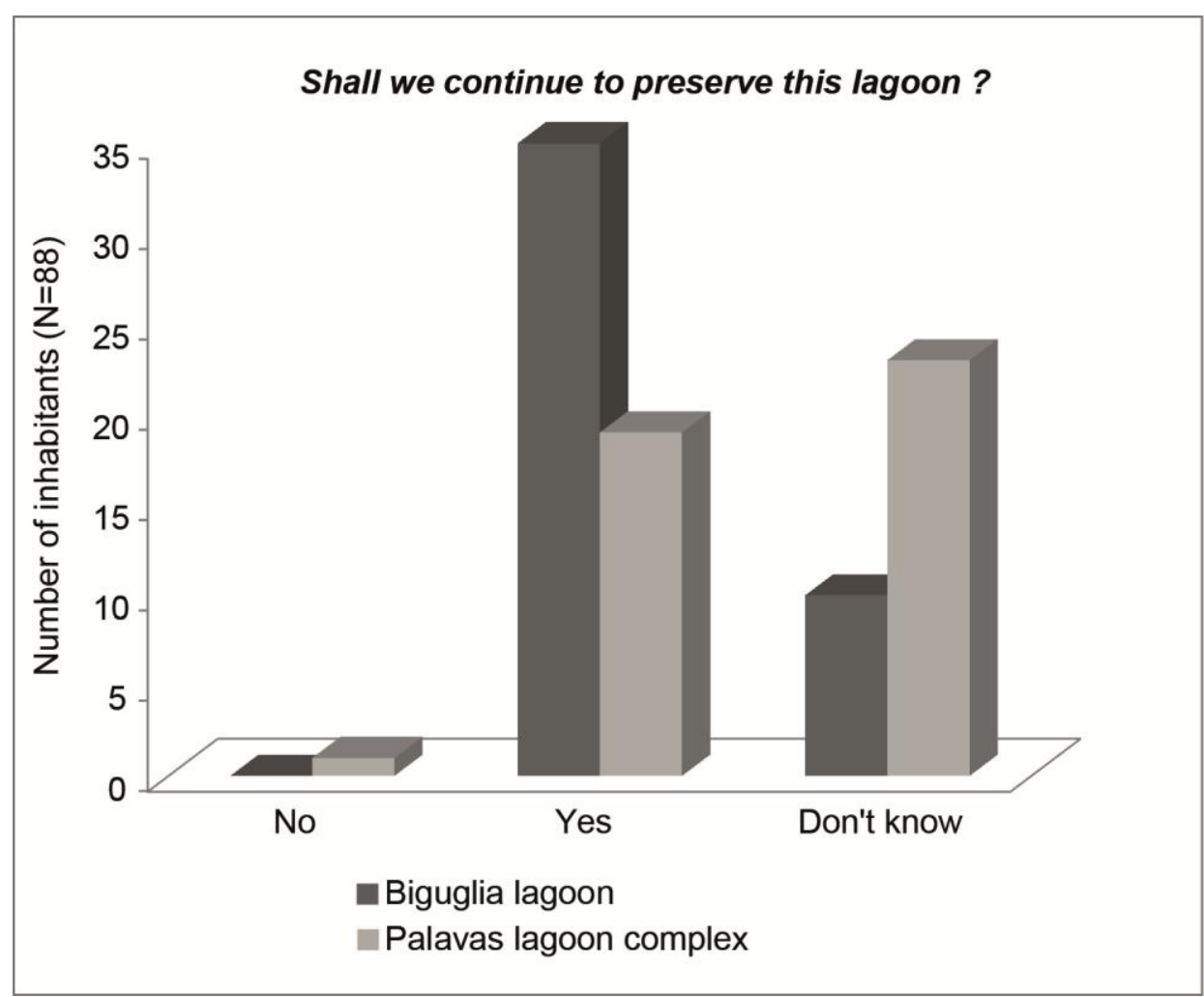

Fig. 7: Opinions of inhabitants about the utility to continue to protect Palavas complex and Biguglia lagoons- (2014) (Survey B)

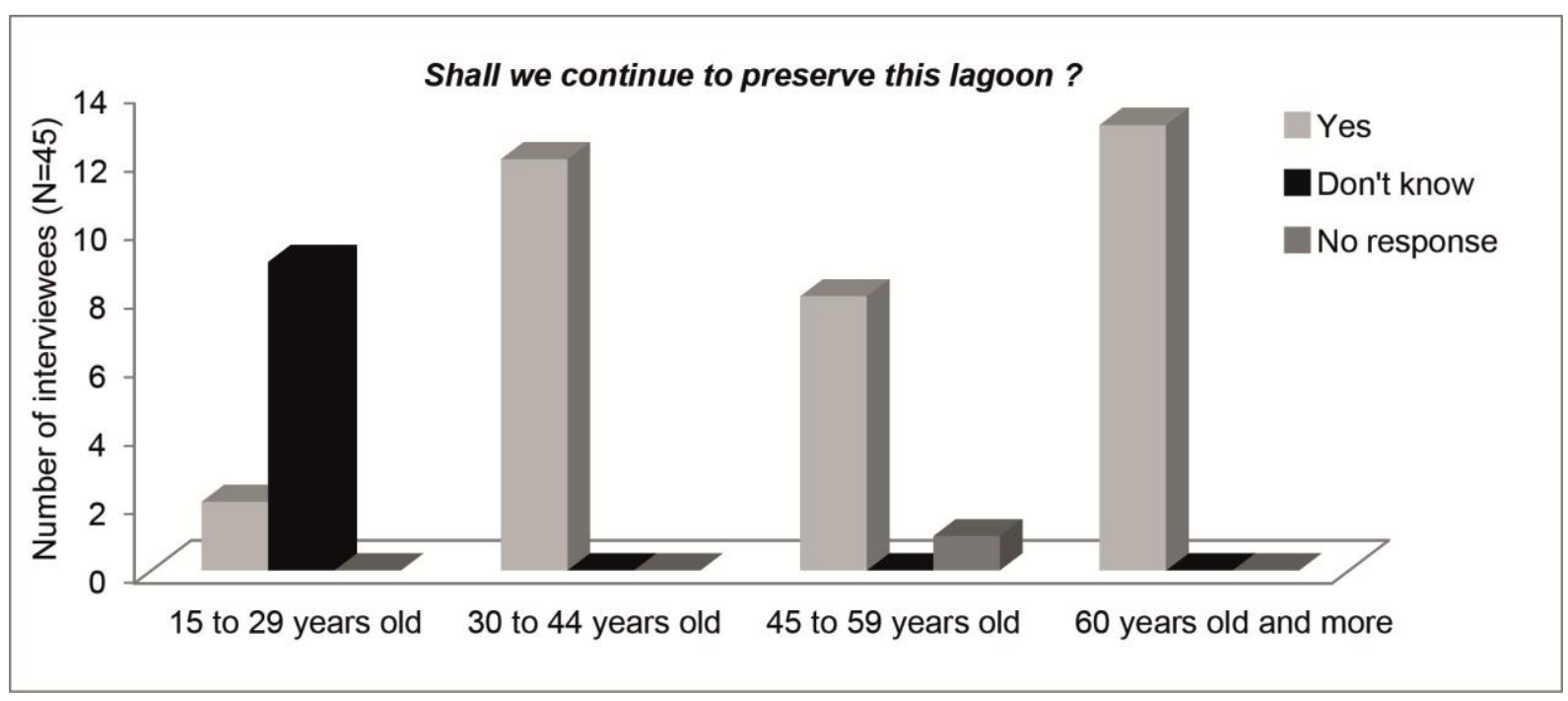

Fig. 8: Effects of the age structure on the opinions of inhabitants about the utility to continue to protect Biguglia lagoon - (2014) (Survey B)

\section{4- Discussion}

\subsection{Managing of lagoon environments: a contributory factor of opinion on the preservation}

The opinions on the utility to continue or not the preservation were different between both lagoons, because the management is different (B Survey) (Fig. 7). Different management structures exist in the Palavas lagoon complex and only a single structure for Biguglia 
lagoon. This matter of fact is reflected by the more fragmented social representations of the Palavas lagoon complex compared to a more unified social representation of Biguglia lagoon. For Palavas lagoon complex, differences between the eastern and western parts of the Palavas lagoon complex reflected different "Ways of living" and perhaps different management practices as well.

For Biguglia lagoon, people perceived the management policy as uniform for the entire lagoon and most of its fringing wetlands, which reflects the fact that there is a single manager. Biguglia lagoon has a single owner, i.e. the County Council of Haute-Corse with its dedicated service "Réserve Naturelle de l'étang de Biguglia" that executes the management. The classification as a nature reserve, as early as 1994, resulted immediately in regulating and forbidding certain activities. Public access is forbidden on the water of the lagoon and is limited to walking paths covering a minor part of its littoral zone. Other management actions targeting biodiversity conservation and improvement of water quality appeared much later. Communication with the general public was initially almost non-existent, although it has improved in recent years since the creation of the Fortin ecomuseum. Despite a low degree of communication in the past, the classification as a protected nature reserve has been fully accepted by the users. Perhaps the "Nature reserve" classification since the 1994 provided a clear signal to the inhabitants highlighting the importance for protecting this wetland.

For Palavas lagoon complex, different managers manage different areas within the lagoon complex. Hence, different management actions have been applied for more than 20 years, originally without creating a coherent scheme at the scale of the whole lagoon complex. Nevertheless, this has improved since the creation of the SIEL syndicate ${ }^{4}$ and the nomination as a Natura 2000 site. In course of time, the local people observed how their freedom of actions has been reduced gradually for the benefit of protection measures that differ, however, according to places. Another study, which was focused on the evaluation of the benefits of ecological restoration of ecosystem lagoons [29], completes the analysis of the results presented in this paper. The perception of the lagoon ecosystems and its associated ecosystem services was studied, more than $85 \%$ of interviewees recognized the need for ecological restoration of Méjean lagoon [29]. Méjean lagoon is one of seven lagoons situated in the East of lagoon complex. While in that study [29], people had been interviewed in Montpellier and in the eastern part of Palavas lagoon complex, in this study presented in this

\footnotetext{
${ }^{4}$ The seven municipalities together with the Montpellier Méditerranée Métropole administration, have created a Syndicat, SIEL (Syndicat Mixte des Etangs Littoraux), whose main role is to act as a facilitator of the Natura 2000 site trying to coordinate the management. This entity also functions as a co-manager of small part of this area.
} 
paper, people of the western part of lagoon complex had been interviewed, who often did not visit Méjean lagoon. Residents of Montpellier often consider Méjean lagoon as an urban park. Hence, the geographical concept of the "Way of living" [30] of local populations differs between the eastern and in the western part of Palavas lagoon complex. This concept takes the subjectivity of inhabitants into account considering that people rethink the landscapes and act on it. Thus, this concept considers the interrelation between the landscapes and the inhabitant, and how both are connected through the subjective representation of practices of places. The residents of the eastern part, would like to be more free and so they would agree a restoration of lagoon only if it don't decrease their freedom.

\subsection{For people, more difficulties to assess water quality than biodiversity}

The implicit reasoning of interviewees (survey $B$ ) is that the water quality is given by the quality of biodiversity and according their activities on the lagoon. The results of bioindicators show a positive trend for the water quality in both lagoon areas (Table 1). The causes of these slow improvements are the reductions of nutrient loadings, ecological restoration and effective management of the lagoons. Several of the biological and physico-chemical quality indicators show improvements although the overall Ecological Quality Ratio may show more conservative behavior during ecosystem restoration due to the principle one out all out. For example, some biological compartments as e.g. phytoplankton show rapid responses, while other processes as e.g. return of Magnoliophyta impacting macrophyte quality indicators may show a high degree of inertia $[4,16,17]$.

In generally, the inhabitants of the two lagoon systems (B survey) show a social representation of water quality that is more optimistic than the ecological assessment based on the bioindicators (Table 1 and Fig. 2). The social representation of water quality is considered in relation to perceptions of biodiversity (Fig.2 and Fig.3). Thus, people cannot evaluate directly the water quality; they perceive it from their appreciation of the importance of biodiversity. Hence, they often attribute a higher quality class to the water quality than according the French WFD assessment.

For two lagoons complex, the interviewees used the fringing wetlands and beaches for the recreational activities (swim facing the sea and not in the lagoon and the hedonistic practices on the fringing wetlands as walks or bicycle riders, picnic...). It was not useful for them to know the water quality because they had no professional links with the lagoon or activities using the water of lagoon. Water quality is not obvious for people and the components of biodiversity are more visible than the bioindicators of water quality. People represent it to themselves from what they can see, as e.g., the presence of solid waste or the presence of 
birds, fishes, and plants. In this study, people saw an improvement of the biodiversity. And yet, biodiversity is very difficult to define in the context of social sciences. The latter also reflected in the answers of the inhabitants; their naturalistic knowledge is vague (Fig.5). In this study, the users and inhabitants (survey A and B) used generic terms to describe the biodiversity a way that was very similar to that observed in a study of the social representation of wetlands in France [31]. Hence, it appears that the wetlands and lagoons are perceived as a landscape rather than as a specific environment that is home for certain species [32]. In fact, for people, the biodiversity is only one constituent element of the landscape. People search for a peaceful nature and wish to enjoy it during very short duration [33,34]. The environment offered by the natural site is essential, but features that are considered as most important are the tranquility, the pleasant nature and the aesthetics, while biodiversity receives less attention [33,34].

The advantages of studying the social representation are to highlight the links between water quality and the biodiversity and to learn about the feeling of people through their knowledge and from what they see. This subjective data is important for managing the lagoon environments. The background aims to know if it is necessary to develop, for the inhabitants and users, a better communication about the state of water quality and about the managing applied to reach a better water quality.

The limitation is this data represent only the trend of subjective judgments of the interviewees, who represent imperfectly the population. And no clarification was given to explain why the interviewees had to choose between high, good, moderate, bad and poor to describe the water quality. Indeed, the result of this study could have been completed by the knowledge about the specific facilities to assess the water quality, yet no question had been integrated on that in the questionnaire.

\subsection{Effects of age on the social representation of lagoon and on the practices}

In Biguglia lagoon, for the oldest interviewed, the iconic landscape of this lagoon represented the former places of recreational and professional fishing; they chose the two photographs which show those places (A and B surveys) (Fig.6). They remembered and kept this image of practices, because in former times, Biguglia lagoon was an important place for recreational and professional fishing for the local population. However, the recreational fishing has been prohibited since twenty years, when the natural reserve was created. Currently, only one professional fisherman works in Biguglia lagoon. The lagoon is still renowned for that, the yield is sold on the local market and a part is exported in Italy. One of the characteristics of the social representations is that they are resistant to incorporate 
changes, a phenomenon known as the anchoring bias [23,35]. Under 29 years old, were less than ten years and a part of them were less than five years when the prohibition of recreational fishing has been decided and implemented. That explains the youngest people choose other photographs than the oldest people. The youngest respondents were not aware of this history. They represented Biguglia lagoon to themselves as a nice landscape, albeit not very accessible and not visible from the coastal plain and from the lido, located between the mountain and the beach, where they develop their recreational activities ( $A$ and B surveys) (Fig.6). The youngest did not know the lagoon or very little, they preferred to enjoy to the beach (on the Lido) (A survey). Those results reflected what the authors saw in the fieldwork from Bastia to the beach (Lido Marana). In Corsica, history, culture, ancient practices are very important for the generation of 45 years old and more [36].

"Photo-based preference judgments have been shown in numerous studies to be highly reliable and of consistent validity. In particular, group-to-group reliability of rating judgments for groups drawn from the same population is generally high, and test-retest reliability is also generally high [...]. And studies have repeatedly shown that judgments of the same areas" [37].

Indeed, for Biguglia lagoon, the results show an effect of age structure on social representation of water quality and thus on opinion to continue or not to preserve the lagoon. One third of the inhabitants close of Biguglia lagoon believed the water quality is bad ( $B$ Survey) (Fig. 2). More people are young, more they doubt on utility to preserve the lagoon (Fig.8) (B survey). The lack of interest of youngest people for lagoon may be an explication. But, the lack of communication about the actions to improve water quality and their results is an valid explanation. Before the 1990s, the water quality was bad, and one among the reasons to create a protected area for this lagoon, was to improve its water quality. As the youngest people did not go to the lagoon, they did not see the difference before the 1990s because they were still too young, in particular for those who were born after 1990. Thus, those people did not know to continue to preserve (B survey) (Fig.8).

\section{Conclusion}

In general, users and residents living close the Palavas and Biguglia lagoons consider that the water quality and biodiversity are moderate or good. For most of them, the current state is better than in the past, which is recognized as being the result of local actions realized by 
management policies. However, collectively the joint approach based on ecology, geography, and sociology underscored the impact of local management policies on social representations. Hence, inconsistencies between social representations and ecological assessments based on bioindicators were detected. The lack of communication about water quality assessments, according WFD methodology, and the management actions designed to improve water quality, lack of knowledge on lagoon biodiversity, and strong anchoring bias all contribute to highly subjective valuation by the resident populations of water quality and biodiversity in coastal lagoons. As observed for many protected areas, the conservation management of these lagoons falls short with respect to addressing the general public. Public awareness of water quality, as well as understanding of the real state and the causes of water quality and biodiversity in coastal lagoons, is necessary to gain support for effective management and to protect or to restore these ecosystems [38]. The inclusion of an assessment of social representations in decision support and communication can make the management more efficient. However, this approach requests that people can visit and enjoy the ecosystems, which implies that a balance must be sought between restrictions and providing the access facilities for various human practices.

\section{Acknowledgements}

Surveys were conducted by TVES team of University of Lille in the framework of the REPERBIPa project (2014-2015). This research was financed by the DRIIHM LabEx, "Device for Interdisciplinary Research on human-environments Interactions" within the framework of the call for projects for the Human-environment observatory "Mediterranean coastline". The Laboratory for Excellence project (LabEx) is supported by the program "Investment in the future" (ANR).

The authors are grateful to the personnel, Magalie Daco and Aïssa Moereo (trainees), involved in the effort carried out in the fieldwork in REPERBIPa project. The authors also thank the Réserve Naturelle de l'étang de Biguglia and the SIEL (for Palavas lagoon complex) which participated in the process of research (in the choice of sites, in the validating of questionnaires, to have to give photos, and welcome of the trainees).

\section{References}

[1] R.S.K. Barnes, Coastal Lagoons, Cambridge University Press, Cambridge, 1980.

[2] D. Sannadurgappa, Interdisciplinary environmental Review, Threats and human influence on coastal ecosystem of Southern India, vol. 11, Issue 4 (2010).

[3] L. W.J. Anderson, Biological invasions, Californa's reaction to Caulerpa taxifolia: a model for invasive species rapid response, 7, (2005) 1003-1016. 
[4] A. Leruste, N. Malet, D. Munaron, V. Derolez, E. Hatey, Y. Collos, R. De Wit, B. Bec, Coastal and Shelf Science, First steps of ecological restoration in Mediterranean lagoons: Shifts in phytoplankton communities, Estuarine, 180, (2016) 190-203, 〈http://www.sciencedirect.com/science/article/pii/S0272771416302037), 2016 (accessed 29.06.16).

[5] M. Lenzi, Sciences of the Total Environment, Experiences for the management of Orbetello Lagoon: eutrophication and fishing, supplement 1992, Elsevier Science Publishers B.V., Amsterdam, 1992.

[6] A. Borja, I. Galparsoro, O. Solaun, - I. Muxica, R.M. Tello, A. Uriarte, V. Valencia, Estuarine Coastal Shelf Sci. 66, The European Water Framework Directive and the DPSIR, a methodological approach to assess the risk of failing to achieve good ecological status, (2006), 84-96.

[7] J. M. Zaldivar, A.C. Cardoso, P. Viaroli, A. Newton, R. De Wit, C. Ibanez, S. Reizopoulou, F. Somma, A. Razinkovas, A. Basset, M. Holmer, N. Murray, Eutrophication in Transitional Waters: an overview, Transitional Waters Monographs 2, (2008) 1-78.

[8] S. Poikane, N. Zampoukas, A. Borja, S. P. Davies, W. van de Bund, S. Birk, Environmental Science \& Policy, Intercalibration of aquatic ecological assessment methods in the European Union: Lessons learned and way forward, (2014), 44, 237-246.

[9] A. Carletti, A.-S. Heiskanen, Water Framework Directive intercalibration technical report, Coastal and Transitional waters. Part 3, European Commission, EUR 23838 EN/3 - Joint Research Centre - Institute for Environment and Sustainability.. - Scientific and Technical Research series - DOI 10.2788/19561

http://publications.jrc.ec.europa.eu/repository/bitstream/111111111/10473/1/3010_08-

[10] D. Rodríguez-Rodríguez, A. Sánchez-Espinosa, C. Schröder, D. Abdul Malak, J. Rodríguez, Marine Pollution Bulletin, Cumulative pressures and low protection: a concerning blend for Mediterranean MPAs, (2015), Vol. 101, 1, 288-295.

[11] K.-C. Tran, J. Euan, M.-L. Isla, Ocean and Coastal management, Public perception of development issues: impact of water pollution on a small coastal community, (2012), vol. 45, 6-7 405-420.

[12] A. Prévost, S. Robert, Land Use Policy, Local spatial planning practices in four French Mediterranean coastal territories under pressure, 56, (2016) 68-80.

[13] Ifremer, 2014 Réseau de Suivi Lagunaire du Languedoc-Roussillon : Bilan des résultats 2013. Rapport RSL-14/2014, $219 \quad$ p. $\quad$ http://www.polelagunes.org/ftp/LettreLagunes/2014/sept/Rapport_RSL_2013_VF.pdf >, 2014 (accessed 05.09.16). 
[14] V. Pasqualini, C. Pergent-Martini, C. Fernandez, L. Ferrat, J. Tomaszewski, G. Pergent, Wetland monitoring: aquatic plant changes in two Corsican coastal lagoons (Western Mediterranean Sea), Aquat. Cons: Mar. Fresh. Ecosyst. 16, (2006) 43-60.

[15] M. Garrido, P. Cecchi, Y. Collos, S. Agostini, V. Pasqualini, Marine Pollution Bulletin, Water flux management and phytoplankton communities in a Mediterranean coastal lagoon, Part I: How to promote dinoflagellate dominance?, 104, (2016) 139-152.

[16] P. Souchu, B. Bec, V.H. Smith, T. Laugier, A. Fiandrino, L. Benau, V. Orsoni, Y. Collos, A. Vaquer, Patterns in nutrient limitation and chlorophyll a along an anthropogenic eutrophication gradient in French Mediterranean coastal lagoons, Can. J. Fish. Aquat. Sci. 67, (2010) 743-753.

[17] A. Sfriso, C. Facca, A. Bonometto, R. Boscolo, Ecological Indicators, Compliance of the macrophyte quality index (MaQI) with the WFD (2000/60/EC) and ecological status assessment in transitional areas: The Venice lagoon as study case, 46, (2014) 536-547.

[18] S. Moscovici, The psychology of the social, The history and actuality of social representations, in U. Flick (Eds.),. Cambridge University Press, Cambridge, 1998, pp. 209247.

[19] S. Moscovici, Why a theory of social representations?, in K. Deaux, G. Philogene (Eds.), Representations of the social, Oxford: Blackwell, 2001, 8-35.

[20] A. Frémond, La région, espace vécu, Coll. SUP, PUF, 1 vol., 1976.

[21] G. Di Méo, Géographie sociale et territoires, Nathan, 1998.

[22] W. Wagner, N. Hayes, Everyday Discourse and Common Sense, The Theory of Social representations, Hampshire, Palgrave, 2005.

[23] B. De Vanssay, Vertigo, Les représentations de l'eau, Hors-série 1, (2003), 〈http://vertigo.revues.org/1959〉, 2003 (accessed 05.05.16).

[24] C. Audouit, C. Rufin-Soler, H. Flanquart, P. Deboudt, G. Le Falher, Représentations et perceptions des acteurs publics et des usagers de la gestion des espaces récréatifs lagunaires. Applications à l'étang de Biguglia (Corse) et aux étangs palavasiens (LanguedocRoussillon) _ REPERBIPa, Report, programme Observatoire « Hommes-Milieux » Littoral méditerranéen, Université Lille et ULCO, TVES EA 4477, (2015).

[25] Hellevik, Ottar (1988). Introduction to causal analysis : Exploring survey data by crosstabulation. Second edition. NY: Oxford University Press.Contemporary social research series, 9

[26] Andral B., Sargian P., 2010. Directive Cadre eau - District "Corse" : Contrôles de surveillance/opérationnel (campagne DCE 2009). Ifremer, France.

[27] Derolez V., Oheix J., Ouisse V., Munaron D., Fiandrino A., Messiaen G., Hubert-Renard C., Lamoureux A., Malet N., Fortuné M., Berard L., Mortreux S., Guillou J.L., 2015. Suivi estival des lagunes méditerranéennes françaises Bilan des résultats 2014. Ifremer, France. 
[28] Pasqualini V., Derolez V., Garrido M., Orsoni V., Baldi Y., Etourneau S., Leoni V., Rébillout P., Laugier T., Souchu P., Malet N., Ecological Engineering, Spatiotemporal dynamics of submerged macrophyte status and watershed exploitation in a Mediterranean coastal lagoon: understanding critical factors in ecosystem degradation and restoration, 2017, 102, 1-14.

[29] R. De Wit, H. Rey-Valette, J. Balavoine, V. Ouisse, R. Lifran, Aquatic Conservation: Marine and Freshwater Ecosystems, Restoration ecology of coastal lagoons: new methods for the prediction of ecological trajectories and economic valuation, (2015), 〈http://onlinelibrary.wiley.com/advanced/search/results〉, 2015 (accessed 12.05.16).

[30] N. Mathieu, «Mode d'habiter : un concept à l'essai pour peser les interactions hommemilieux«, in: R. Chenorkian, S. Robert, Les interactions hommes-milieux - questions et pratique de la recherche en environnement, ED Quae, Plaine Saint-Denis, 2014, pp. 97-130.

[31] M.R. Saïdi, Représentation sociale des zones humides - Enquête d'opinion, CNRS LADYSS, DESMIS, MEDDTL, Report, 2012, «http://85.31.222.100/alexandrie7/dyn/portal/index.seam;jsessionid=429aa592a51 bb04f53f2a17b1226?alold=5602\&page=alo \&cid=336), (accessed 18.05.16).

[32] L. Goeldner-Gianella, C. Imbert, L'Espace géographique, Représentations sociales des marais et dépoldérisation : le cas d'un marais breton, tome 34 (2005) 251-265,

〈www.cairn.info/revue-espace-geographique-2005-3-page-251.htm.〉 (accessed 31.05.12).

[33] B. Kalaora, Au-delà de la nature, l'environnement ; l'observation sociale de l'environnement, L'Harmattan, 1998.

[34] V. Andreu-Boussut, La nature et le balnéaire - le littoral de l'Aude, L'Harmattan, Paris, 2008.

[35] D. Kahneman, P. Slovic, A. Tversky, Judgment under uncertainty: Heuristics and biases, Cambridge University Press, New York, 1982.

[36] Bergues A., Le Lien au lieu, Bastia, Éditions Éoliennes, 2014, 304.

[37] Brown, T. C., Richards, M. T., Daniel, T. C., \& King, D. A., 1989, Journal of Leisure Research, Recreation participation and the validity of photo-based preference judgments. 21(1), 40.

[38] C. M. Duarte, W. C. Dennison, R. J. W. Orth, T. J.B. Carruthers, Perspective in estuarine and coastal sciences, The charisma of coastal ecosystem: addressing the imbalance, 31 (2008) 233-238. 
Annexe Table : Physicochemical quality of water, Phytooplancton quality classes and Macrophyte quality classes. (Ifremer, 2014 Réseau de Suivi Lagunaire du LanguedocRoussillon)

Physicochemical quality of water. The bounderies between classes are mentioned. The variable showing the lowest quality status is used for the aggregated quality class (one out all out).

\begin{tabular}{|c|c|c|c|c|c|c|c|c|c|c|}
\hline & & High & & Good & & Moderate & & Poor & & Bad \\
\hline Colour code & & & & & & & & & & \\
\hline Variable & Unit & & & & & & & & & \\
\hline Turbidity & NTU & & 5 & & 10 & & 25 & & 40 & \\
\hline Inorganic phosphate & $\mu \mathrm{M}$ & & 0.3 & & 1 & & 1.5 & & 4 & \\
\hline $\begin{array}{l}\text { Dissolved Inorganic } \\
\text { Nitrogen (DIN) }\end{array}$ & $\mu \mathrm{M}$ & & 2 & & 6 & & 10 & & 20 & \\
\hline Nitrite & $\mu \mathrm{M}$ & & 0.3 & & 0.5 & & 0.75 & & 1 & \\
\hline Nitrate & $\mu \mathrm{M}$ & & 1 & & 3 & & 5 & & 10 & \\
\hline Ammonium & $\mu \mathrm{M}$ & & 1 & & 3 & & 5 & & 10 & \\
\hline Chlorophyl-a & $\mathrm{mg} \cdot \mathrm{m}^{-3}$ & & 5 & & 7 & & 10 & & 20 & \\
\hline Total nitrogen & $\mu \mathrm{M}$ & & 50 & & 75 & & 100 & & 120 & \\
\hline Total phosphorus & $\mu \mathrm{M}$ & & 0.75 & & 1.5 & & 2.5 & & 4.5 & \\
\hline
\end{tabular}

Phytooplancton quality classes. The bounderies between classes are mentioned. The variable showing the lowest quality status is used for the aggregated quality class (one out all out).

\begin{tabular}{|l|c|c|c|c|c|c|c|c|c|c|}
\hline \multicolumn{2}{|l|}{} & High & & Good & & Moderate & & Poor & & Bad \\
\hline Colour code & Unit & & & & & & & & & \\
\hline Variable & & & & & & & & & \\
\hline $\begin{array}{l}\text { Cell number } \\
\text { Picophyto-plankton }< \\
2 \mu \mathrm{m}\end{array}$ & $\begin{array}{c}10^{6} \text { Cells L } \\
1\end{array}$ & & 20 & & 50 & & 100 & & 500 & \\
\hline
\end{tabular}




\begin{tabular}{|l|c|c|c|c|c|c|c|c|}
\hline $\begin{array}{l}\text { Cell number Phyto- } \\
\text { plankton }>2 \mu \mathrm{m}\end{array}$ & $\begin{array}{c}10^{6} \text { Cells } \mathrm{L}^{-} \\
\mathrm{y}\end{array}$ & 2 & & 5 & & 10 & & 50 \\
\hline
\end{tabular}

\begin{tabular}{|c|l|l|}
\hline Macrophyte quality classes & $\begin{array}{c}\text { Colour } \\
\text { code }\end{array}$ & \\
\hline High & & $\begin{array}{l}\text { The reference species are dominant covering }>75 \%, \text { Opportunistic } \\
\text { macroalgae may be present locally }\end{array}$ \\
\hline Good & $\begin{array}{l}\text { The reference species dominate covering between } 50 \text { and } 75 \%, \\
\text { Opportunistic macroalgae may be present locally }\end{array}$ \\
\hline Moderate & $\begin{array}{l}\text { The reference species are present, but not dominant (cover between } 5 \\
\text { and } 50 \%) . \text { Opportunistic algae proliferate and may cause recurrent } \\
\text { dystrophic crises. }\end{array}$ \\
\hline Poor & $\begin{array}{l}\text { Reference species are present at less than } 5 \% \text { coverage. } \\
\text { Opportunistic species do not predominate permanently, but may cause } \\
\text { general dystrophic crises. Species number }>3\end{array}$ \\
\hline Bad & $\begin{array}{l}\text { Reference species are absent; only opportunistic speciesmay } \\
\text { proliferate and cause general and recurrent dystrophic crises. Species } \\
\text { number < 3. }\end{array}$ \\
\hline
\end{tabular}

